\title{
THE EFFECTS OF THE WATSU METHOD ON FUNCTIONAL CAPACITY, ANXIETY AND DEPRESSION IN PATIENTS WITH PARKINSON DISEASE
}

\section{Ribeiro IR}

Student of Physical Therapy in the State University of Pará; ingridribei112@gmail.com; https://orcid.org/0000-0002-2933-7112.

\section{Lima FLC}

Student of Physical Therapy in the State University of Pará; ferlucca4@gmail.com; https:// orcid.org/0000-0003-3401-9597.

\section{Rosa TB}

Student of Physical Therapy in the State University of Pará; belemthati@gmail.com, https://orcid.org/0000-0003-1876-1353.

\section{Santos RM}

Student of Physical Therapy in the State University of Pará; renan-maues@hotmail.com; https://orcid.org/0000-0003-0172-9699.

\section{Costa SAF}

Student of Physical Therapy in the State University of Pará; Biologist; samiaflor.bio@gmail. com; https://orcid.org/0000-0001-9046-6792.

\section{Souza DM}

Professor of Physical Education at the Metropolitan College of the Amazon ; Danielem. souza14@gmail.com; https://orcid.org/0000-0002-0420-0638.

\section{Dias GAS}

ProfessoratthePhysical TherapyCourse of theStateUniversity of Pará; georgealbertodias@ yahoo.com.br; https://orcid.org/0000-0002-9807-6518. 


\section{Santos CAS}

Professor at the Physical Therapy Course of the State University of Pará; Rua do Una, 156, 66050-540, Belém, Pará, Brasil; cesylamazon@gmail.com; https://orcid.org/OoO0003-4745-781X.

Abstract: Parkinson's disease (PD) is a chronic and progressive pathology that results from the degeneration of the black substance responsible for the voluntary control of movements. The reduction of dopamine generates motor and non-motor symptoms that hinder the mobility of the patient and the execution of their activities of daily living. The Watsu method relieves pain, tension and releases the muscles, fascias and spine leading to the gain of flexibility and range of motion, and can be a facilitator in reducing the symptoms of PD. The aim was to evaluate the effects of the Watsu method on motor and non-motor symptoms and their relation with the functional capacity of these individuals. This is an experimental study applied to 4 male patients diagnosed with PD. The analyzed variables were: anxiety, depression, quality of life, basic and instrumental activities of daily living and balance. 9 Watsu sessions was applied. Student's t-test (paired sample) was carried out to compare the variables studied. There was no significant improvement in the variables analyzed, but there was a tendency for improvement in quality of life variables (before 38.75 and later 36.50), depression (before 23 and after 21.25) and instrumental activities of daily living (before 19.50 and later 20.75). For the variables anxiety, basic activities of daily living and balance there was no improvement of these variables. It was observed that the Watsu method trends to improve motor and no-motor symptoms that affect the PD patients. In addition, there is still a lack in the literature in studies that use the Watsu method as a treatment for both PD and other diseases.

Keywords: Watsu Method. Functional capacity. Parkinson's disease.

\section{INTRODUCTION}

Parkinson's disease (PD) is a chronic and progressive condition that results from the degeneration of the compact part of the black substance of the midbrain that projects dopaminergic fibers to the caudate nucleus and to the putamen responsible for voluntary movement control. PD is the second most frequent neurodegenerative disease in the population, behind only Alzheimer's disease. It is associated with aging and its prevalence 
is $1 \%$ in the elderly population, over 60 years in underdeveloped countries. Regarding sex, PD is equally prevalent in both sexes, although males are slightly more affected., ${ }^{1,2}$ Due to dopaminergic dysfunctions, PD presents motor and non-motor symptomatology.

The reduction of dopamine in the substantia nigra and in the limbic system decreases the impulse for motor activity, mainly generating: rest tremor, rigidity, bradykinesia and postural instability. ${ }^{3}$ These symptoms are caused by a slow transmission of motor information, balance disorders, changes in the coordination of agonist and antagonist muscle contraction and reduction of muscle strength. ${ }^{2-4}$

Decreased dopamine also leads to the development of non-motor symptoms such as decreased olfaction, constipation, dysphagia, urinary urgency, orthostatic hypotension, sleep disorders, dementia, apathy, anxiety and depression. ${ }^{5,6}$ Depression is a state of unpleasant mood, loss of interest in the world and anguish that manifests itself in alternating days lasting more than four months. Some symptoms of depression, such as slow movement and apathy, may be confused with PD symptoms, which makes diagnosis more difficult. Anxiety disorder is as common as depression in PD, and is characterized by a stress activated by situations that present no real danger to the individual, presenting manifestations such as tremor, sweating, palpitation, tachycardia, increased blood pressure and dry mouth. ${ }^{6,7}$

In this sense, the limitations of PD are determinant for the decrease and even loss of functional capacity (FC). The realization of activities of daily living depends on the demands of the individual, the task to be performed and the environment. FC is, therefore, the ability to respond in an integrative way to all of these requirements to accomplish a task. Concepts such as autonomy and dependence are related to individual FC. ${ }^{8,9}$ It is noteworthy that patients with PD who have total or partial reduction of their FC are more susceptible to the development of depressive symptoms. ${ }^{10}$

As the disease progresses, changes in posture, gait and balance disorders make it difficult for the patient to move and perform their daily activities. In addition, it causes reduction in muscle strength as well as postural instability, exacerbating the risk of falls, dependence and decreased social interactions, negatively impacting the quality of life of these individuals. ${ }^{11-13}$ 
From this scenario, the Watsu method is a technique used in heated swimming pool $\left(35^{\circ}\right)$, the patient is floating and the therapist performs passive stretching movements in order to achieve a deep state of relaxation. Heat and movements performed by the therapist will relieve pain, tension and release the muscles, fascia and spine leading to the gain of flexibility and range of motion enabling a greater mobilization of the patientss body segments. Watsu acts not only in the physical aspects, but also in the emotional and psychological aspects, as it allows contact with emotions that are not allowed to be delivered during the day-to-day. Being on the therapist's lap and being wrapped in water brings the patient a sense of welcome and support, and a relationship of trust is established between the two, in which the therapist will always respect the patient's boundaries. ${ }^{14}$

Thus, the objective of this study was to evaluate the effects of the Watsu method on motor and non-motor symptoms and its relation with functional capacity.

\section{MATERIALS AND METHODS}

\subsection{ETHICS APPROVAL}

The research began after approval of the Research Ethics Committee of the University of the State of Pará (UEPA) (no. 3.077.499).This is an experimental study, carried out at the University of the State of Pará (UEPA), at the Center for Biological Sciences of Health (CCBS) Campus II, at the Professor Benedito José Ribeiro Duarte Hydrotherapy Clinic. Participants were selected through non-probabilistic sampling for convenience.

\subsection{SAMPLE}

Four individuals participated in the study from March to August 2018. As inclusion criteria, patients with a diagnosis of Parkinson's disease, both sexes, aged between 40 and 70 years, were referred from the Unit's Neurofunctional Physiotherapy department of Teaching and Assistance in Physiotherapy and Occupational Therapy (UEAFTO). We 
excluded individuals with inconclusive diagnosis of PD, who had lesions on the skin and hemodynamic instability.

The following questionnaires were used in the evaluation of the patients: Beck Anxiety Inventory (BAI), to assess anxiety in isolation, without being confused with depression pictures; Beck Depression Inventory (BDI) describing affective and somatic cognitive behavioral manifestations of depression; Katz Index, evaluates hierarchically related life activities, and is organized to measure functional capacity in the performance of six functions such as: bathing, dressing, going to the toilet, transferring, having continence and eating; Tinneti's Scale, which evaluates the patient's balance; and the Parkinson's Disease Questionnaire-39 (PDQ-39), an instrument of easy application that has been widely used in research on the quality of life of individuals with PD.

After the evaluation the patients were submitted to the Watsu method. The session took place in a therapeutic pool 8 meters wide by 8 meters long and 1.50 meters deep, with water heated to $35^{\circ} \mathrm{C}$, as foreseen by the technique. Each participant was accompanied until he was in the water and in the proper place to start the Watsu session, leaning against the pool wall with his shoulders at the water level. Floats were placed on the lower limbs to facilitate flotation.

It was used the basic movements of the technique, as follows: Dance of the breath, offering slow, releasing the column, offering with one leg, offering with both legs, accordion, accordion with rotation, rotation with the leg from within, rotation with leg from outside, accompany the movement holding a leg (inner), algae (shoulder support), quietude and heart lullaby. The choice of these movements was based on the needs and limitations of the patients combined with the therapeutic objectives established for the study. The sessions had an average duration of 1 hour for each patient, twice a week.

\subsection{STATISTICAL ANALYSIS}

Excel® 2010 software was used for data entry and table creation, as well as BioEstat 5.0 for statistical analysis. Numerical variables were presented by means of central 
Ribeiro IR et al.

tendency measures (mean). Student's t-test (paired sample) was carried out to compare the variables studied. The alpha level of significance was set at $5 \%(p<0.05)$.

\section{RESULTS}

A total of 4 individual of male sex participated the study, with mean age 60.5 years, totaling 9 Watsu sessions, as shown in Table 1.

\begin{tabular}{ll}
\multicolumn{2}{l}{ Table 1 - Descriptive analysis of patients with Parkinson's disease. } \\
\hline Variables & $\mathrm{n}(\%)$ \\
\hline Age & 60.5 years \\
Sex & \\
Female & $4(100 \%)$ \\
Average Watsu sessions & - \\
\hline
\end{tabular}

(-) Numeric data equal to zero.

Regarding quality of life, a reduction in the score was observed after Watsu session, which means a better perception of the quality of life but without statistic significant $(p=0.18)$. When evaluated the anxiety, it was possible to notice an increase in scores after the Watsu sessions, reflecting an increase in anxiety in these patients, but without statistical significance $(p=0.58)$. For depression levels, even showing that patients were classified with moderate to severe depressive symptoms, a reduction of the means obtained was observed. Leading to believe that there was a tendency to improve for this variable (Table 2).

Table 2 - Analysis of the non-motor variables of patients with Parkinson's disease submitted to the Watsu method

\begin{tabular}{llll}
\hline Non-Motor Variables & Before & After & p-value \\
\hline PDQ-39 & 38.75 & 36.50 & 0.18 \\
Beck Inventory for Anxiety & 17.25 & 21.75 & 0.58 \\
Beck Inventory for Depression & 23 & 21.25 & 0.70 \\
\hline PDQ-39 (Parkinson'sDiseaseQuestionnaire - 39). Teste t Student (Paired sample), $\mathrm{p} \leq 0,05$.
\end{tabular}


In the instrumental activities of daily life, it was possible to observe an increase in the scores obtained, reflecting an increase in the independence to carry out the activities. In the basic daily life activity, the patients are semi-dependent. Finally, in the analysis of the balance it was possible to observe that even after the Watsu sessions the patients present a high risk of falling, as shown in table 3.

Table 3 - Analysis of the motor variables of patients with Parkinson's disease submitted to the Watsu method

\begin{tabular}{llll}
\hline Motor Variables & Before & After & p-value \\
\hline AIVDs & 19.50 & 20.75 & 0.43 \\
ABVDs & 7.25 & 8.25 & 0.25 \\
Tinetti's Scale & 20.25 & 18.25 & 0.39 \\
\hline
\end{tabular}

Note: AIVDs (Instrumental Activities of Daily Living); ABVDs (Basic Activity of Daily Living). Teste t Student (Paired sample), $\mathrm{p} \leq 0,05$.

\section{DISCUSSION}

It was observed in the present study a tendency to improve the quality of life (QOL) of patients with Parkinson's disease, corroborating with the findings of Silva ${ }^{15}$ where aquatic exercises were used, finding improvements in the QOL of 18 patients after 16 sessions. Vasconcelos, ${ }^{16}$ found a significant improvement in the quality of life of 10 patients after 24 sessions of aquatic physiotherapy. In their protocols both used heating, stretching, exercises for upper and lower limbs and relaxation, similar to the protocol used in this work. Thus, the sample size and the number of sessions were determinant for the results found. In addition, according to Stdeidl, ${ }^{17}$ depression is a risk factor for PD, just as PD is a risk factor for depression, it occurs in approximately $40 \%$ of patients diagnosed. According to Silberman, ${ }^{18}$ depression in parkinsonian patients is associated with the advancement of PD severity. Based on this, Barreto ${ }^{19}$ highlight the role of dopamine produced in the black pathway ranging from control of movement to regulation of mood and stress, schizophrenia and anxiety. Many pathologies are caused by the decrease of the dopamine in the organism, hindering the human daily life. As an example of diseases presented by the decrease of this neurotransmitter are: Parkinson's disease (PD) and depression. In this sense, Silva ${ }^{15}$ emphasize that one of the effects caused by immersion in aquatic environment would be the increase of dopamine levels in 
the central nervous system, which remain for a few hours after immersion. According to Oliveira, ${ }^{20}$ in addition to physical and chemical signs evident and proven through studies, the psychological action of treatment is positive, since direct contact between physiotherapist and patient promotes trust between both parties.

The basic and instrumental activity variables of daily living were also evaluated. According to Moreira, ${ }^{21}$ as a consequence of the limitations and disabilities associated with $P D$, individuals become dependent on others to perform their basic and instrumental activities of daily living. In the view of Freitas, ${ }^{* *}$ the hydrotherapy has the benefit of muscle strengthening, reduction of trunk rigidity as well as improved movement and coordination, favoring patient independence and facilitating achievement of daily activities. ${ }^{22}$ For Cunha $^{* * *}$ water supports and minimizes biomechanical stress in muscles and joints, with improved self-esteem, confidence, and functionality. ${ }^{23 \mathrm{v}}$

According to Ferreira and Matsunani ${ }^{24}$ the temperature, which revolves around $33^{\circ}$ to $35^{\circ}$, results in adequate muscle relaxation, improving sleep, decreasing insomnia and, consequently, decreasing anxiety and tiredness. For Lima ${ }^{25}$ the Watsu Method provides a state of deep relaxation, presenting benefits to mental and physical health, as well as enhancing the individual's ability to cope with stress, tension and anxiety.

For the variables of balance and gait it was observed worsening of these individuals, diverging from the study of Ortega ${ }^{26}$ with 10 patients with Parkinson's disease who underwent hydrokinesis therapy, where they had an increase in balance and gait scores, but this was not statistically significant. PD is a chronic degenerative disease and therefore it is difficult to obtain improvements in motor aspects, but a retardation of its progress, as observed in the study already mentioned. Janovick ${ }^{27}$ obtained an improvement in the balance after the application of aquatic exercises, going in disagreement with the present study, which did not show improvement in balance and gait.

22 Costa IF, Barbosa LS, Carvalho VM, Sousa VLB, Souza YS. Redução da funcionalidade no envelhecimento: a fisioterapia aplicada na qualidade de vida do idoso. In: Proceedings of X Semana de Iniciação Científica da Faculdade R. Sá. June 2016. Picos, Piauí, Brasil; 2016. 


\section{CONCLUSION}

It was possible to observe a trend of improvement in the psychological, emotional and physical aspects in the patients studied, even though it did not present significant results, being evident in the perception of the quality of life, the depressive levels remained moderate to severe, but the score obtained in the scale presented reduction after application of the Watsu Method. Regarding the instrumental activities of daily living, there was an increase in the score, leading to consider the possibility that after the application of the Watsu method, the patients presented greater ease and autonomy to perform such activities. However, in relation to the evaluation of basic daily activities, balance and anxiety levels, it was not possible to observe a reduction of the symptoms in these variables, according to the evaluation of the scores.

In addition, it is worth mentioning that there are few documents in the literature about the effects of the Watsu Method on the functional capacity of individuals with PD, showing the psychological, emotional and physical aspects, especially the physical that is the precursor agent of limitations in other areas. It is necessary to produce studies that use not only the Watsu Method, but also other methodologies to evaluate and direct the treatment of the framework in question, providing these individuals, especially in the domains of mobility, activities of daily living, levels of depression and anxiety and especially their quality of life.

\section{CONFLICT OF INTEREST}

There is no conflict of interest related to the research.

\section{REFERENCES}

1. Steidl E, Ziegler J, Ferreira F. Doença de Parkinson: Revisão Bibliográfica. Disc. Scientia. 2007;8(1):115-29. 
Ribeiro IR et al.

2. Samii A, Nutt JG, Ransom BR. Parkinson's Disease. The Lancet. 2004;363(9423):178393.

3. Guyton AC, Hall JE. Tratado de fisiologia médica. 12th ed. Rio de Janeiro: Elsevier; 2011.

4. Silva J, Dibai Filho A, Fagnello F. Mensuração da qualidade de vida de indivíduos com a Doença de Parkinson por meio do questionário PDQ-39. Fisioter Mov. 2011;24(1):141-6.

5. Adler C, Beach T. Neuropathological basis of non-motor manifestations of Parkinson's disease. Mov Disord. 2016;31(8):1114-9.

6. Mueller C, Rajkumar AP, Wan Y, Velayudhan L, Ffytche D, Chaudhuri KR, et al. Assessment and Management of Neuropsychiatric Symptoms in Parkinson's Disease. CNS Drugs. 2018;32(7):621-635.

7. Kandel E, Schwarts J, Jessell T, Siegelbaum S, Hudspeth A. Princípios de Neurociências. 4th ed. Porto Alegre: Artmed; 2014.

8. Shumway-Cook A, Woollacott M. Controle Motor: teoria e aplicações práticas. 3rd ed. Barueri: Manole; 2010.

9. Ferreira LL, Cavenaghi OM. Capacidade funcional em idosos com doença de parkinson: revisão de literatura. Saúde Ver. 2017;17(47):73-81.

10. Silva PCS, Fernandes ACBC, Terra FS. Avaliação da depressão e da capacidade funcional em idosos com doença de parkinson. Revenferm UFPE. 2014;8(7):1920-7.

11. Nocera Jr, Buckley T, Waddell D, Okun MS, Hass CJ. Knee extensor strength, dynamic stability, and functional ambulation: are they related in Parkinson's disease? Arch Phys Med Rehabil. 2010;91(4):589-95.

12. Bertoldi F, Silva J, Faganello-Navega F. Influência do fortalecimento muscular no equilíbrio e qualidade de vida em indivíduos com doença de Parkinson. Fisioter Pesq. 2013;20(2):117-22.

13. Soares L, Pereira A, Magno L, Figueiras H, Sobral L. Equilíbrio, marcha e qualidade de vida na Doença de Parkinson: efeitos de um tratamento de vibração de corpo inteiro. Fisioter Mov. 2014;27(2):261-270.

14. Dull H. Watsu: exercícios para o corpo e na água. 1st ed. São Paulo: Summus; 2001.

15. Silva DM, Nunes COM, Oliveira PJAL, Coriolano MGWS, Berenguer FA, Lins OG, et al. Efeitos da Fisioterapia aquática na qualidade de vida de sujeitos com doença de Parkinson. Fisioter Mov. 2013;20:17-23. 
16. Vasconcelos KS, Santos JNG, Rocha RSB, Oliveira LSO. Percepção da qualidade de vida na doença de Parkinson após fisioterapia aquática. Saúde Ver. 2015;15(39):17-23.

17. Silberman CD, Laks J, Rodrigues CS, Engelhardt E. Uma revisão sobre depressão como fator de risco na Doença de Parkinson e seu impacto na cognição. Rev Psiquiatr. 2004;26:52-60.

18. Barreto MAM, Marinho AA, Silva KKM, Fermoseli AFO, Jesus CLPF. As conseqüências da diminuição da dopamina produzida na substância nigra: uma breve reflexão. Interfaces Científicas - Saúde e Ambiente. 2015;4(1):83-90.

19. Oliveira LS. Hidroterapia como tratamento complementar em pacientes com depressão clinica diagnosticada [monografy]. Roraima: Faculdade de Educação e Meio Ambiente; 2013.

20. Moreira RPCS. Impacto da doença de Parkinson na qualidade de vida de indivíduos nas fases leve e moderada [master's thesis]. Curitiba: Universidade Federal do Paraná; 2014.

21. Luz KPS, Coronago VMMO. A doença de Parkinson na pessoa idosa e relação com sua qualidade de vida. Id on Line Rev Psic. 2017;11(35):116-36.

22. Costa IF, Barbosa LS, Carvalho VM, Sousa VLB, Souza YS. Redução da funcionalidade no envelhecimento: a fisioterapia aplicada na qualidade de vida do idoso. In: Proceedings of X Semana de Iniciação Científica da Faculdade R. Sá. June 2016. Picos, Piauí, Brasil; 2016.

23. Ferreira KB, Matsutani LA. Abordagem da Hidroterapia no tratamento da fibromialgia. Revista PIBIC. 2006;3(2):39-47.

24. Lima AARL, Pereira KS, Vinhas R. Efeitos do Método Watsu em paciente asmático moderado- relato de caso. Rev Neurocienc. 2009;17(20):283-6.

25. Ortega JS, Oliveira TL, Oliveira DV, Benedeti MR, Bertolini SMMG. Avaliação da Marcha, Equilíbrio e Qualidade de vida em indivíduos com a doença de Parkinson submetidos ao tratamento por meio da hidroterapia. Revista Inspirar. 2014;6(4):11-15.

26. Jankovick J. Parkinson's disease: clinical features and diagnosis. J Neurol Neurosurg Psychiatry. 2008;79:368-76. 
